\title{
Classification of the natural vegetation of Mtendere Game Ranch in the Chibombo District of the Central Province, Zambia
}

\author{
A.E. Cauldwell, U. Zieger, M.G. Bingham and G.J. BredenKamP
}

Cauldwell, A.E., U.Zieger, M.G. Bingham and G.J. Bredenkamp. 1998. Classification of the natural vegetation of Mtendere Game Ranch in the Chibombo District of the Central Province, Zambia. Koedoe 41(2): 13-26. Pretoria. ISSN 0075-6458.

A phytosociological analysis of the physical environment and the natural plant communities of Mtendere Game Ranch in the Chibombo District of the Central Province of Zambia is presented. A TWINSPAN classification and DECORANA ordination based upon 69 relevés revealed three vegetation types, grassland, woodland and thicket, that are subdivided into the following plant communities: Dambo, Munga Woodland, Miombo Woodland, Termitaria and Deciduous Thicket. The natural vegetation of Mtendere Game Ranch is separated into fire management units on the basis of the vegetation types.

Key words: habitat utilisation; Miombo; wildlife; Zambia; TWINSPAN; DECORANA

A.E. Cauldwell $(\square)$ and U. Zieger, Centre for Wildlife Management, University of Pretoria, Pretoria, 0002 Republic of South Africa; M.G. Bingham, Private Bag X31, Woodlands, Lusaka, Zambia; G.J. Bredenkamp, Department of Botany, University of Pretoria, Pretoria, 0002 Republic of South Africa.

\section{Introduction}

To manage natural resources in step with nature, it is essential to conduct baseline environmental surveys. Vegetation classification and mapping are prerequisites for ecologically and economically sound land-use planning, resource management, sustainable utilisation and other conservation programmes (Edwards 1972). The purpose of this study was to classify and describe the natural vegetation of Mtendere Game Ranch in the Central Province of Zambia, with the aim to identify fire management units. The study was based upon a field survey in 1996. Some areas of Mtendere Game Ranch were once cleared of vegetation for cultivation. The vegetation there is now regenerating and represents a diversity of vegetation units, but these are excluded from this study because they no longer represent the natural vegetation.

\section{Study Area}

Mtendere Game Ranch $\left(15^{\circ} 05^{\prime} 40^{\prime \prime S}\right.$, $\left.28^{\circ} 16^{\prime} 05^{\prime \prime} \mathrm{E}\right)$ is located in the Chibombo
District of the Central Province of Zambia. The ranch covers an area of approximately 960 ha. The study area is neighboured to the east by the Kamaila State Forest and to the south by the Karubwe State Forest. Lusaka is the nearest urban centre and lies approximately $20 \mathrm{~km}$ to the south. The altitude of the region varies from $1100 \mathrm{~m}$ to $1200 \mathrm{~m}$ above sea level.

\section{Climate}

Three ecological seasons, which are based upon temperature and rainfall, are recognised (Hutchinson 1974). These are: the warm rainy season from December to April, the cool dry season from May to August and the hot dry season from September to November. Rainfall in this region is controlled essentially by the arrival and departure of the Intertropical Convergence Zone, but is also influenced in the early rainy season by the Zaire Airmass (Acharya \& Bhaskara Rao 1981). The mean annual rainfall for the study area is $830 \mathrm{~mm}$ ( $n=14$ years). The climate characteristics of the study area are summarised in Fig. 1. 


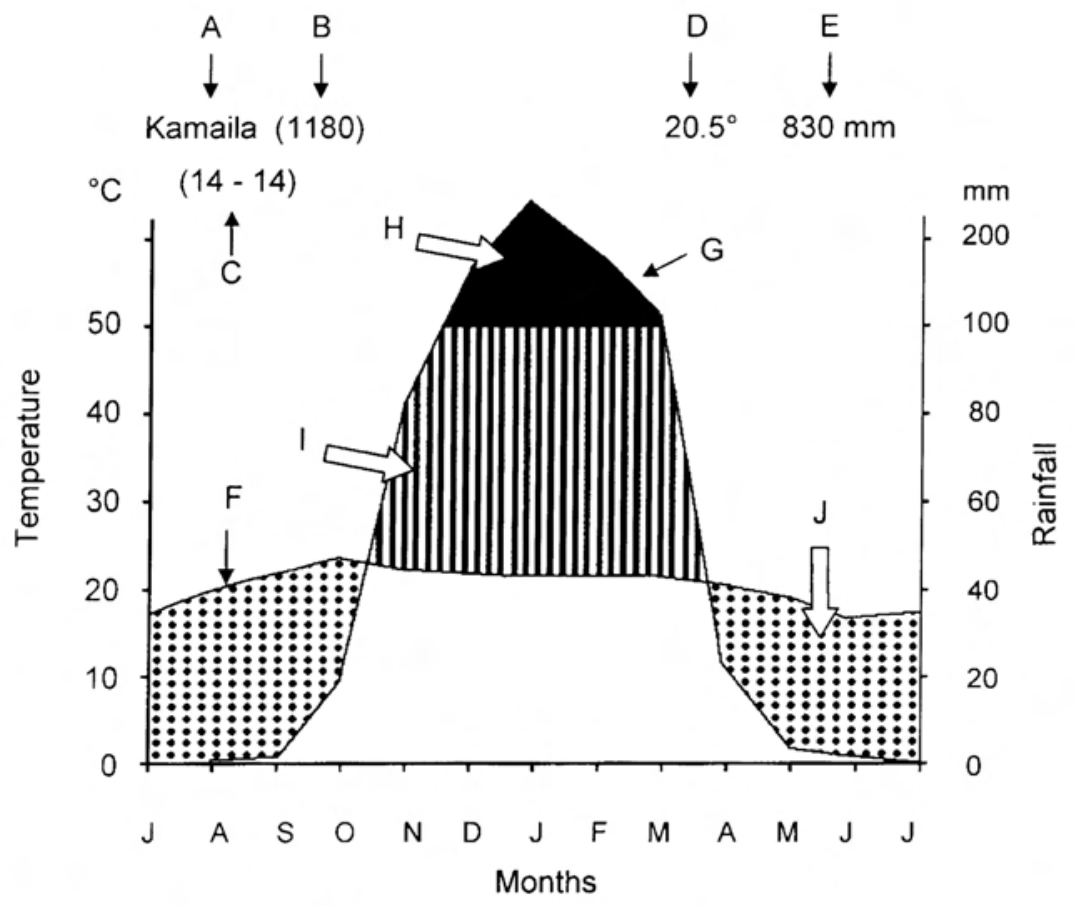

Fig. 1. Climatic diagramme for the Kamaila State Forest headquarters located approximately $5 \mathrm{~km}$ east of Mtendere Game Ranch in the Central Province, Zambia to show the monthly temperature and rainfall means for a period of 14 years (Walter 1963; Zambia Meteorological Department 1996). where: $\mathrm{A}=$ Kamaila weather station; $\mathrm{B}=$ altitude $(\mathrm{m}) ; \mathrm{C}=$ duration of observations in years (temperature and rainfall respectively); $\mathrm{D}=$ mean annual temperature $\left({ }^{\circ} \mathrm{C}\right) ; \mathrm{E}=$ mean annual rainfall $(\mathrm{mm}) ; \mathrm{F}=$ mean monthly temperature $\left({ }^{\circ} \mathrm{C}\right) ; \mathrm{G}=$ mean monthly rainfall $(\mathrm{mm}), \mathrm{H}=$ perhumid period (black area), mean monthly rainfall above $100 \mathrm{~mm}$ (scale reduced 10 times); $\mathrm{I}=$ humid period (hatched area); $\mathrm{J}=$ dry period (dotted area).

\section{Topography}

The topography of the region is characterised by gently undulating terrain. The study area is drained by dambos that are typical for the Miombo Biome (Hough 1986). Dambos are seasonally waterlogged drainage lines with no clear water channels (Bolnick 1995). With the exception of the dambos, the topography plays a minor role in the determination of vegetation patterns and there is no obvious toposequence.

\section{Vegetation types}

Zambia is located entirely within the Zambezian phytoregion that stretches from northern Tanzania to northern South Africa and from Angola to Mozambique (White 1983). The phytoregion is separated into the following five broad vegetation types: dry forest, swamp and riparian forest, grassland, thicket and woodland. Woodlands are separated into Miombo, Chipya and Munga (Fanshawe 1971). Miombo Woodland lies between latitudes $5^{\circ} \mathrm{S}$ and $20^{\circ} \mathrm{S}$ and constitutes the largest single vegetation type in southern Africa (Hough 1986). White (1983) separates Miombo Woodland into wet and dry types separated from one another by the $1000 \mathrm{~mm}$ mean annual rainfall isohyet. Chidumayo (1987) further subdivides the Dry Miombo into the following three subtypes: Central Dry Miombo, Eastern Dry 
Miombo and Kalahari Sand Woodland. The study area is located within the Central Dry Miombo Region. In this region the Miombo Woodland clearly dominates the vegetation, and only small areas of other vegetation types occur. These are grasslands (dambo), thickets which include termitaria thickets and dry deciduous thickets, and woodlands which include Chipya and Munga woodlands.

\section{Soils}

Dambos, which support tall grasslands, are based upon seasonally waterlogged soils. Two distinctly different soil formations are recognised between the upper and lower reaches of the dambos. The drier upper reaches of the dambos occur on sandy soils with clear $\mathrm{E}$ and $\mathrm{G}$ horizons. The B horizons of such soils are distinctively mottled with concretions that give rise to the development of soft plinthic B horizons. Examples of hard plinthic B horizons occur that may be exposed and appear as small rocky outcrops along the dambo edges. The other soil formation is found along the lower, wetter reaches of the dambos and are based upon soils with a vertic A horizon up to a depth of $1 \mathrm{~m}$. This horizon is composed of black clay, and overlays $\mathrm{G}$ and $\mathrm{B}$ horizons with distinctive mottling and development of concretions.

The Miombo and Deciduous Thicket vegetation types in the study area are found on well-drained shallow soils, which range from yellow sand to a reddish sandy clay and overlay a deep reddish quartz gravel. Outcrops of quartz appear occasionally. The soils are leached and acidic, being deficient of organic matter and minerals (Astle 1969; Trapnell et al. 1976; Lawton 1978). No significant differences occur between soils of the Miombo or Chipya woodlands (Astle 1969; Lawton 1978).

Soils of the Munga Woodlands consist of a sandy clay A horizon with occasional E horizons and the development of concretions in the $\mathrm{B}$ horizons.
The termitaria thickets within the study area are found on numerous large termite mounds with a diameter that may reach $12 \mathrm{~m}$ and a height of up to $5 \mathrm{~m}$. Termites of the genus Macrotermes are the initial builders, but later these mounds may be colonised by up to 10 other types of termite (Trapnell et al. 1976). Termites create the soils of the mounds. These soils are known to have carbon and mineral contents up to five times higher than that of the surrounding soils (Trapnell et al. 1976).

\section{Methods}

Relevés were compiled for 69 sample plots. Stratification was based upon vegetation types (Fanshawe 1971; White 1983). A plot size of $30 \mathrm{x}$ $30 \mathrm{~m}$ was used to represent the diversity of the woody vegetation, which in many cases contained large tree specimens. Large wooded termitaria were sampled individually. The floristic composition of each sample was recorded using the Braun-Blanquet cover abundance scale (Mueller-Dombois \& Ellenberg 1974). Scale unit 2 was divided into the following categories (Werger 1974): 2A which covers $5-12 \%$ of the sample plot area and $2 \mathrm{~B}$ which covers 13-25\% of the sample plot area. Nomenclature follows Flora Zambesiaca, or alternatively Arnold \& De Wet (1993) where the former is not yet complete. The structural classification was based upon Edwards (1983). The following habitat data were recorded in each plot: tree height, grass height, horizontal visibility, canopy cover, rockiness, soil characteristics and indications of burning and utilisation. Soil characteristics were determined from samples obtained to a depth of $1.2 \mathrm{~m}$ using an auger. The utilisation of plant communities by game was visually observed on a regular basis for a full year.

To derive at a first approximation of the vegetation units, a two-way indicator species analysis (TWINSPAN) (Hill 1979a) was applied. This was refined further by Braun-Blanquet procedures (Behr \& Bredenkamp 1988). A detrended correspondence analysis (DECORANA) (Hill 1979b) was also applied to the floristic data set to illustrate the relationships between the vegetation and the environmental parameters.

\section{Results and discussion}

The results of the refined TWINSPAN are presented in a phytosociological table (Table 


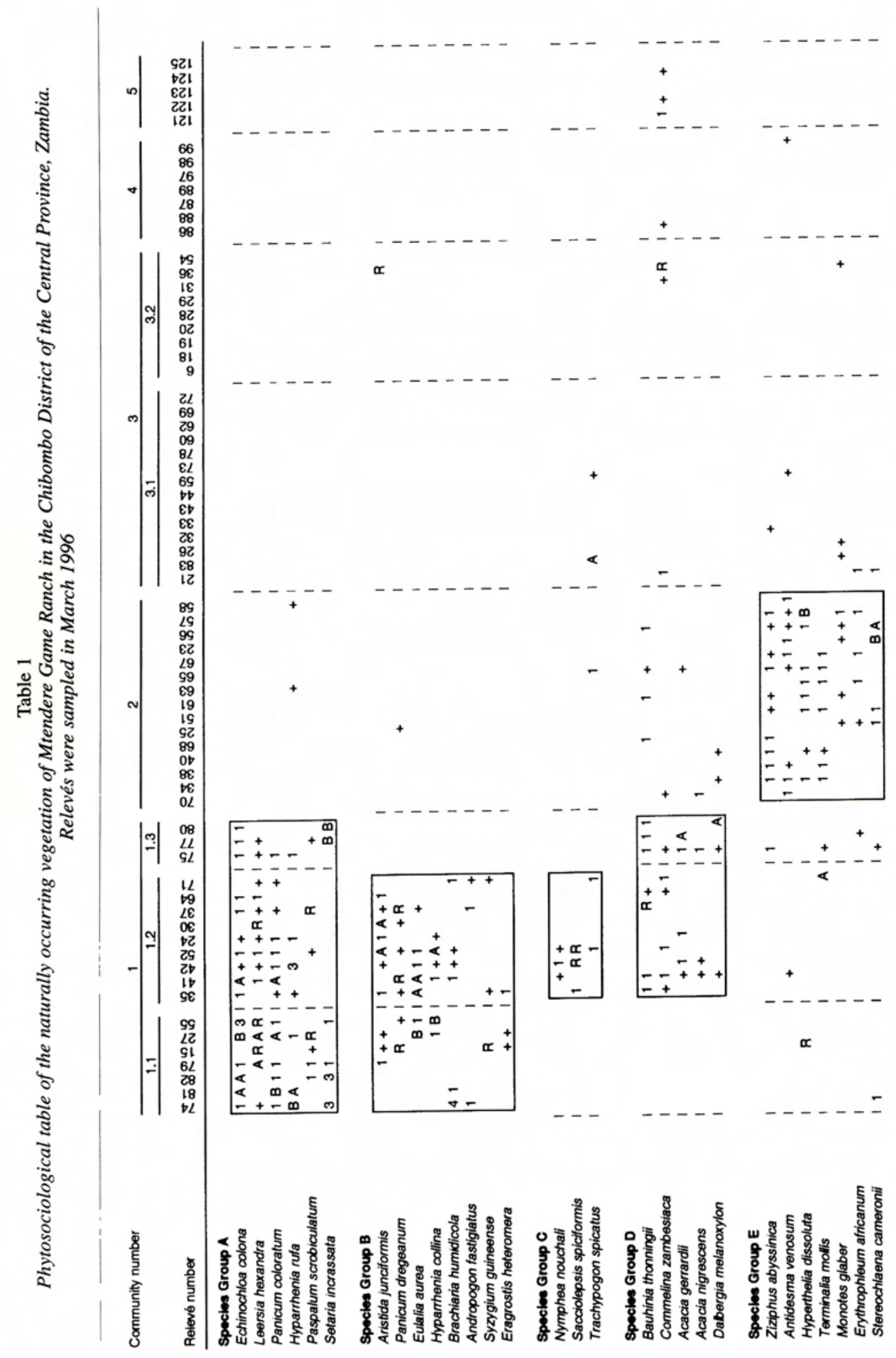




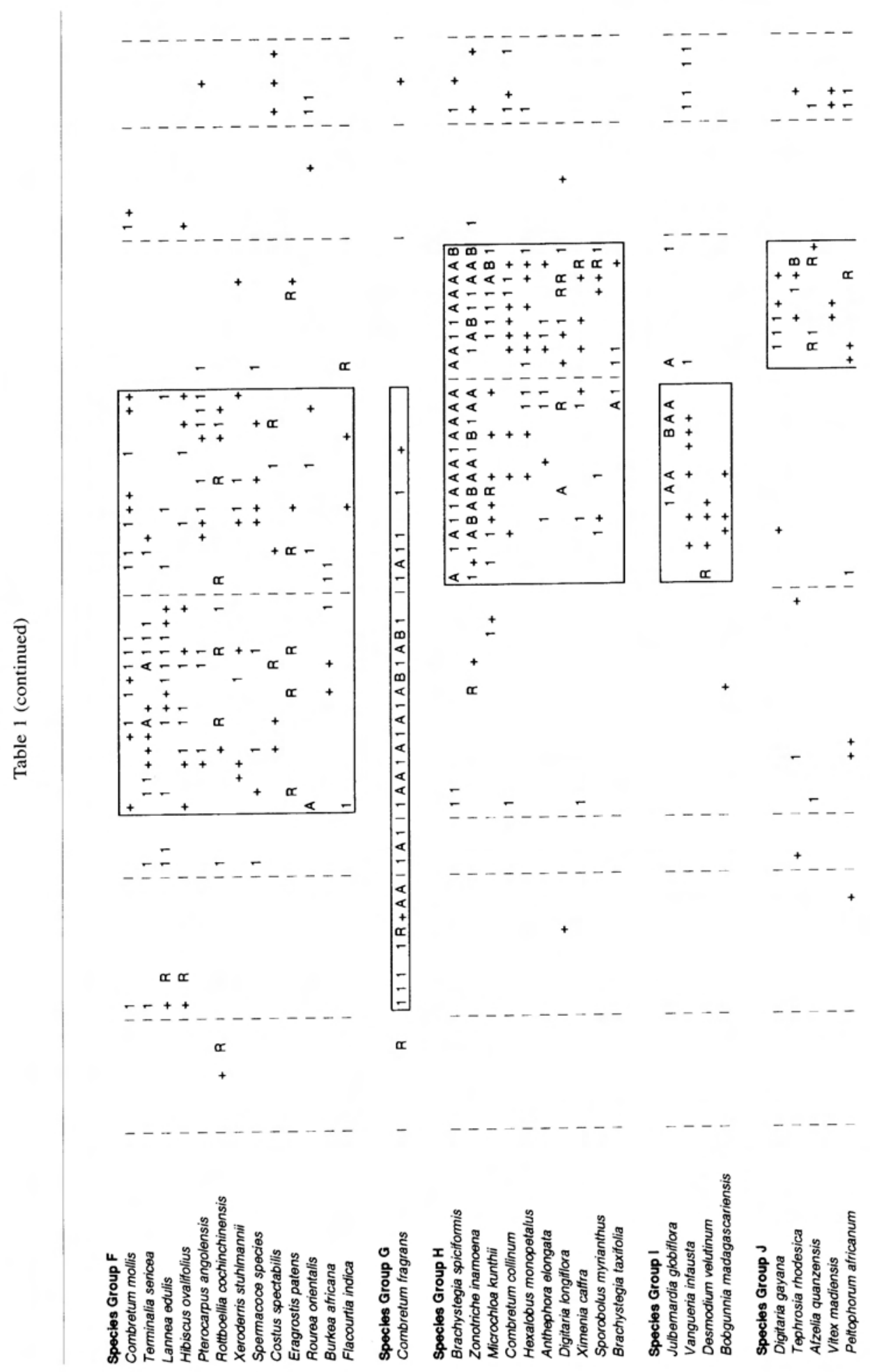




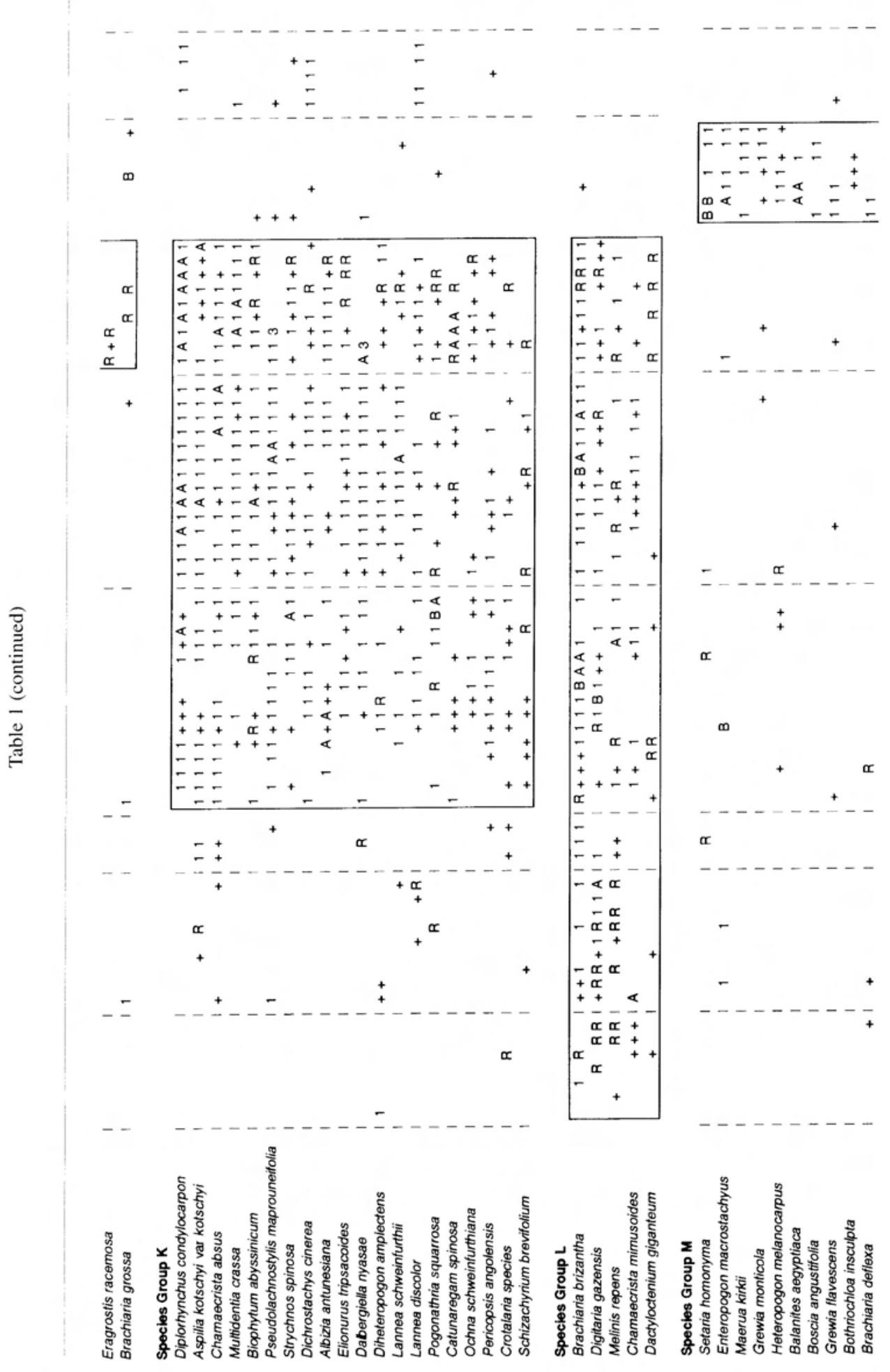



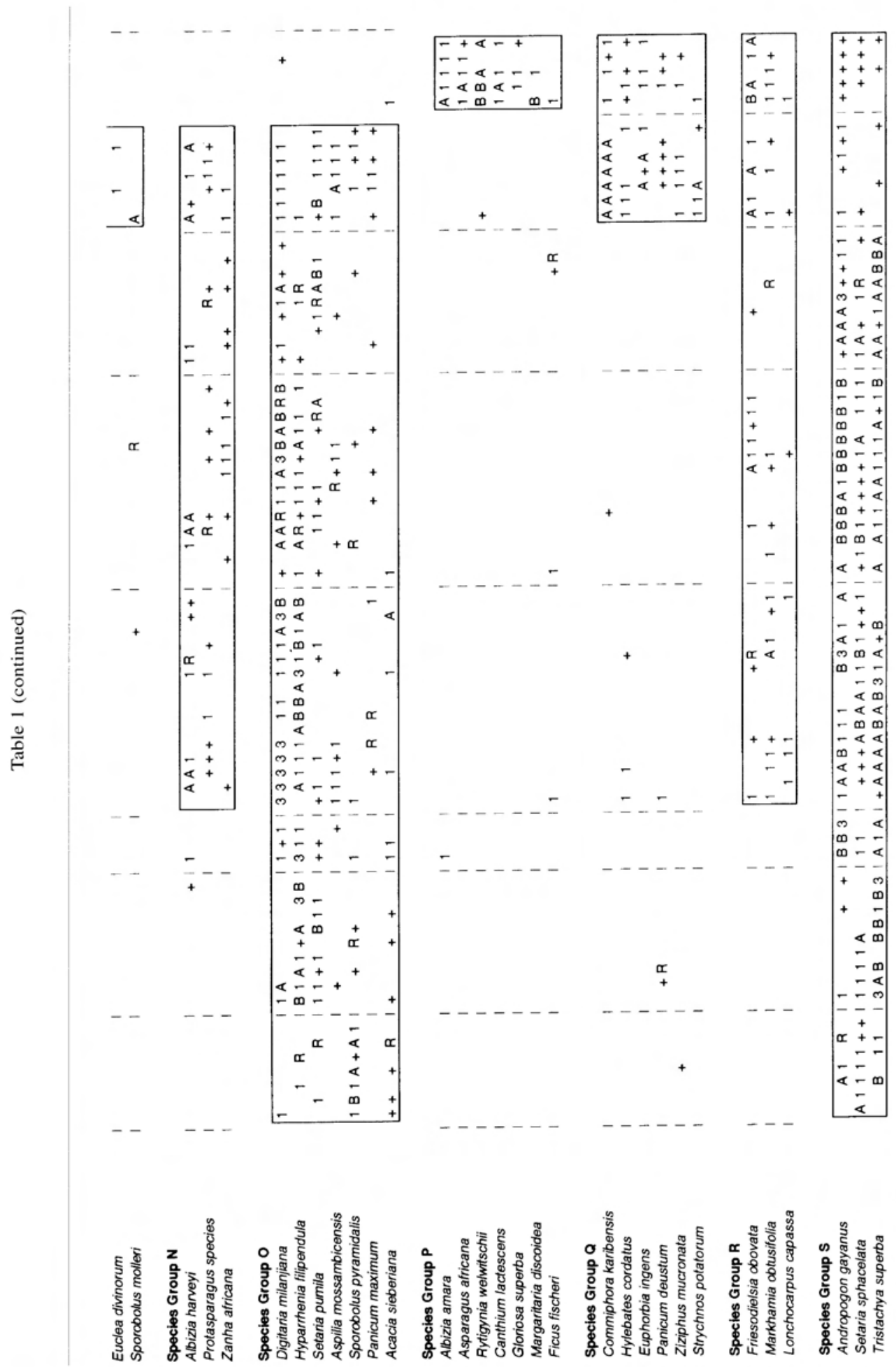


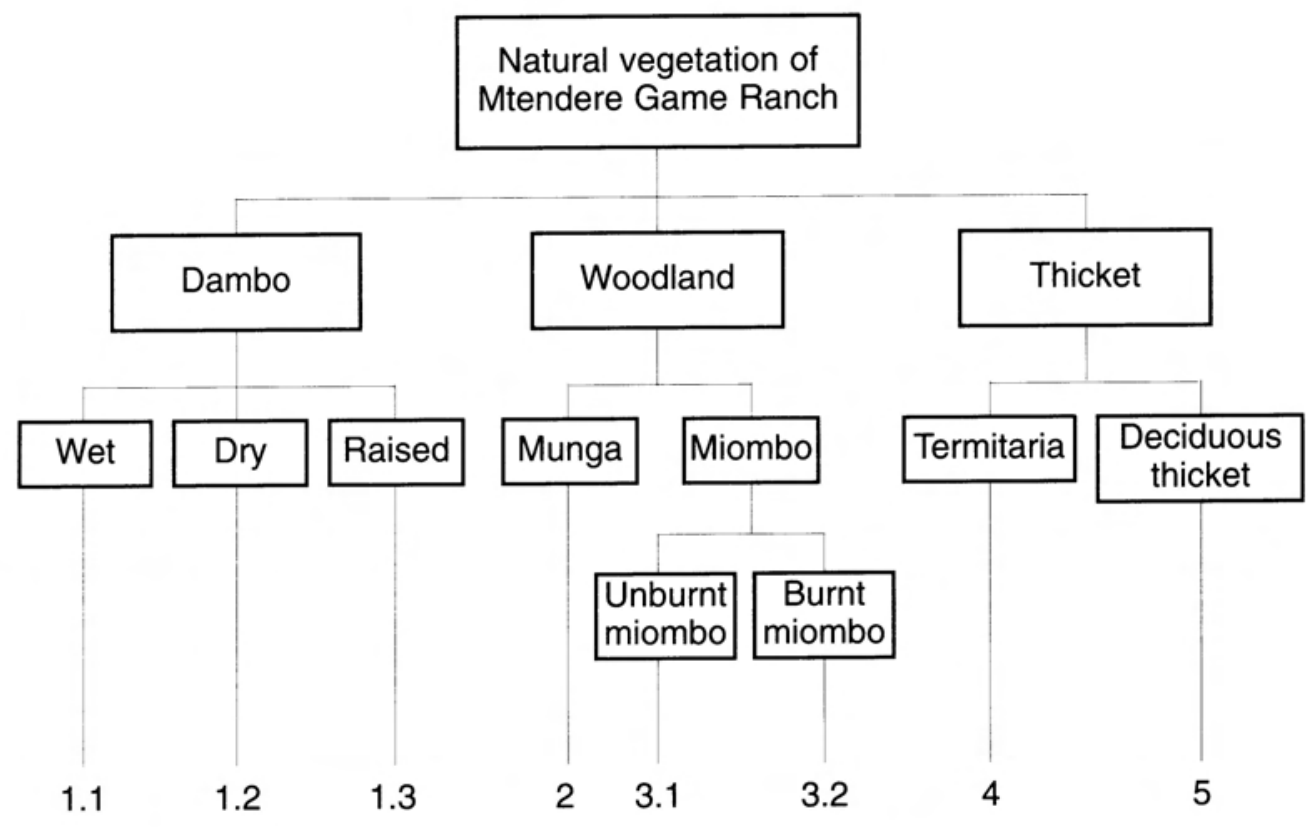

Fig. 2: Hierarchical dendrogram to illustrate the relationships between naturally occurring vegetation types and plant communities of Mtendere Game Ranch in the Chibombo District of the Central Province, Zambia.

1). The hierarchical relationships between the vegetation units appear in Fig. 2.

\section{Description of the plant communities}

The plant communities of Mtendere Game Ranch are characterised by the constant presence of the grasses Andropogon gayanus, Setaria sphacelata and Tristachya superba (species group $\mathrm{S}$, Table 1). The mean number of species recorded per relevé was 38 , with a range of 19 to 56 . Three main vegetation types are recognised. These are separated into five plant communities, of which two are further separated into three and two variations respectively to give a total of eight vegetation units. Their layout is illustrated in Fig. 3. They are:
1. Echinochloa colona - Acacia sieberiana Seasonally Wet Grassland community (dambo)

This grassland community is characterised by species group A (Table 1). Common grasses occurring throughout this community are Echinochloa colona, Leersia hexandra and Panicum coloratum. Woody plants are widely separated, but are dominated by Combretum fragrans. Acacia sieberiana and Bauhinia thonningii are conspicuous components because of the sparse nature of the woody vegetation.

This grassland community encompasses all of the dambos within the study area. Drainage is predominantly subterranean, although many small pools are present during the wet season. Tall grasses dominate the 


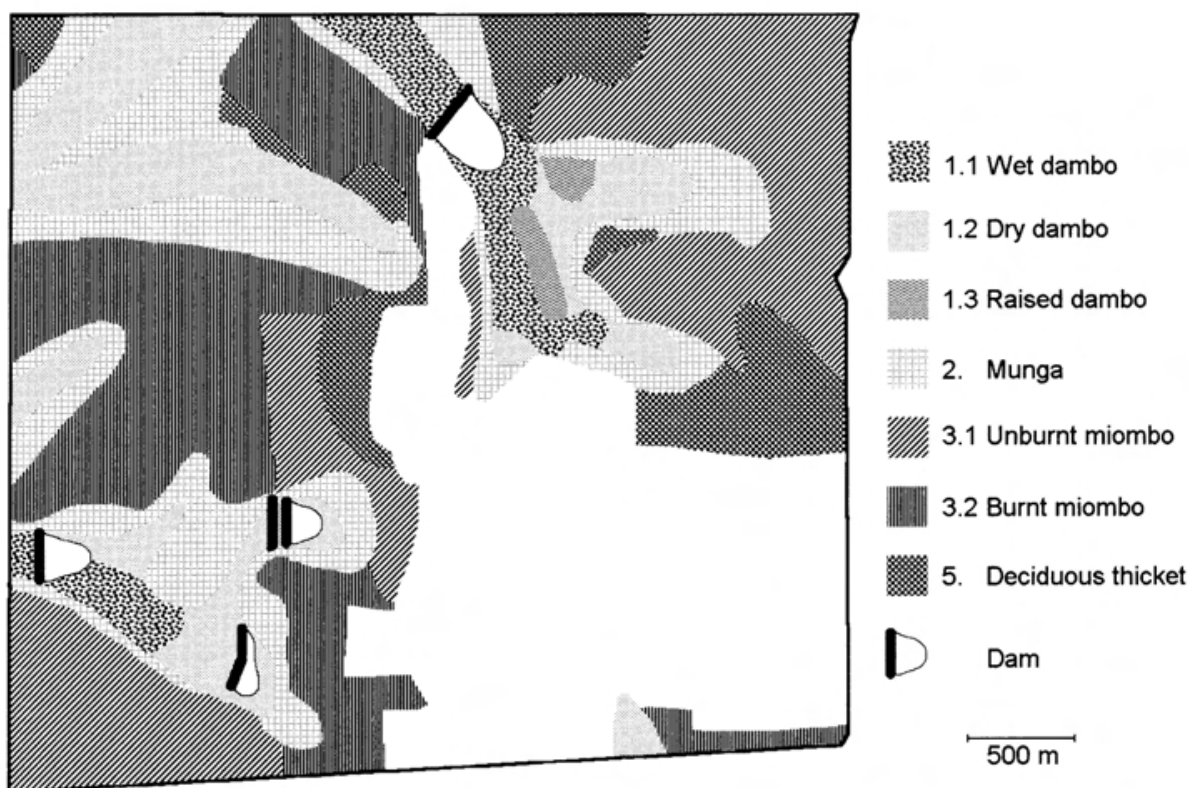

Fig. 3. Layout of the natural vegetation units of Mtendere Game Ranch in the Chibombo District of the Central Province, Zambia. The blank areas in this illustration represent vegetation that was once cleared for cultivation, but is excluded here as it no longer represents the natural vegetation.

vegetation throughout this community and ground cover is generally high. The vegetation of these wet grasslands varies from year to year, particularly the abundance of Echinochloa colona, depending upon the extent of flooding or waterlogging of the soil. The dense grass sward produces large fuel loads that can support intense fires during the dry seasons.

Three variations based upon various soils and moisture regimes are recognised within this community.

\subsection{Echinochloa colona - Leersia hexandra High Closed Grassland variation (wet dambo)}

This dambo variation is described from seven relevés and is characterised by the absence of species groups $\mathrm{C}$ and $\mathrm{D}$ (Table 1). The dominant grass species are Echinochloa colona, Hyparrhenia rufa and Setaria incrassata. Apparent dominance within the grass sward varies through the season, with Echinochloa colona and Setaria incrassata flowering and being visually dominant in January and February. Hyparrhenia rufa is not easily detected visually at this time of year, but it flowers and becomes visually dominant during April. Woody plants are sparse in this variation, but occasional Acacia polyacantha and Acacia sieberiana trees do occur.

This high grassland occurs along the lower reaches of the drainage lines. The soils become waterlogged during the rainy and post-rainy seasons. During periods of high rainfall, water flows can be detected over the surface. Access for both man and animals is hampered during the mid to late rainy season because of the wet soils. The grass layer is dense, with a mean height of $2 \mathrm{~m}$ during the rainy season. Many grasses are palatable and 
are well-utilised by game during the dry season.

1.2 Panicum dregeanum - Acacia sieberiana Tall Closed Grassland variation (Dry Dambo)

This dambo variation is described from nine relevés and is characterised by species group C (Table 1). Hyparrhenia filipendula and Tristachya superba dominate the grass sward, but Sacciolepis spiciformis and Trachypogon spicatus are diagnostic grass species. Acacia sieberiana, Bauhinia thonningii, Combretum fragrans and Ziziphus abyssinica are abundant and conspicuous woody species but are not diagnostic for this variation.

This dambo variation occurs on the upper reaches of the drainage lines and occasionally forms a narrow zone along the outer edges of the previous variation. It is characterised by the presence of numerous small 'tombstone' termite mounds approximately 300 $\mathrm{mm}$ high built by termites of the genus Cubitermes (Trapnell 1976). Grasses dominate this variation but many small Combretum fragrans trees are present because of a lack of fire in the recent past. Eland Taurotragus oryx showed a preference for the browse available in this variation.

\subsection{Echinochloa colona - Bauhinia thon- ningii Short Open Woodland variation (raised dambo)}

This variation is described from three relevés and contains no diagnostic plant species, but it is characterised by the absence of species groups $\mathrm{B}$ and $\mathrm{C}$ (Table 1). The dominant grasses are Andropogon gayanus, Brachiaria brizantha, Echinochloa colona, Setaria sphacelata and Tristachya superba. Characteristic woody species in this community are Acacia gerrardii, Acacia nigrescens, Acacia polyacantha and Dalbergia melanoxylon.

This variation occurs on a slightly raised area within the Wet Dambo variation and it possibly develops from upliftment of the unstable vertic soils. The soils in this varia- tion are similar to the soils of the Wet Dambo variation, but they are slightly raised and therefore do not become fully waterlogged. As a consequence, this variation supports a limited diversity of woody species, and shows some similarity with the woodland communities. Tall grasses, with a mean height of $1.2 \mathrm{~m}$, are the most abundant plant species within this variation. These grasses are mostly palatable and this variation is well-utilised by many types of game for most of the year.

\section{Stereochlaena cameronii - Ziziphus} abyssinica Tall Closed Woodland community (Munga)

This community is described from 15 relevés and is characterised by species group E (Table 1). Antidesma venosum, Erythrophleum africanum, Terminalia mollis and Ziziphus abyssinica are diagnostic woody plant species. Other common woody species are Albizia harveyi, Diplorhynchus condylocarpon, Erythrina abyssinica and Parinari curatellifolia. Stereochlaena cameronii is a diagnostic grass species that appears to increase in abundance under moderate grazing pressure. The grass component of this community is characterised by an abundance of Andropogon gayanus, Brachiaria brizantha, Digitaria milanjiana, Hyparrhenia filipendula, Setaria sphacelata and Tristachya superba.

This community resembles the Munga Woodland as described by Fanshawe (1971). The word Munga means thorn in the Bemba language. This woodland community has an open park-like appearance, with many trees and thorn-bearing shrubs up to a mean height of $11 \mathrm{~m}$. It forms an intermediate zone between the seasonally wet dambos and the other woodlands of the study area. This community forms a buffer zone that reduces the impact of the hot fires, which originate in the dambos, on the fire tender Miombo Woodlands. The woody vegetation consists of fire tolerant species, although many trees show scars from previous fire damage. Grasses are abundant within this community 
and they provide grazing that is well-utilised by a wide variety of game throughout the year.

3. Brachystegia spiciformis - Zonotriche inamoena High Closed Woodland community (Miombo)

This woodland community covers the greatest part of the naturally occurring vegetation of the study area and it is typical of the Central Dry Miombo of Zambia (Chidumayo 1987).

This community is characterised by species group H (Table 1). Dominant and diagnostic woody species are Brachystegia spiciformis, Combretum collinum and Hexalobus monopetalus. Other common woody species in this community are Catunaregam spinosa, Dalbergiella nyasae, Lannea discolor, Ochna schweinfurthiana, Pericopsis angolensis, Strychnos spinosa and Ximenia caffra. Anthephora elongata and Zonotriche inamoena are diagnostic grasses within this community.

Miombo Woodlands are fire tender and their floristic composition is altered by fire (Trapnell 1959; Lawton 1978). Uncontrolled fires have occurred irregularly in the study area. This community is therefore separated into two variations based upon the impact of these fires on the species composition and woody structure.

\subsection{Brachystegia spiciformis - Elionurus tripsacoides High Closed Woodland variation (unburned Miombo)}

This Miombo variation is described from 14 relevés and is characterised by species group I (Table 1). Bobgunnia madagascariensis, Julbernardia globiflora and Vangueria infausta are diagnostic woody species. Brachystegia spiciformis, Diplorhynchus condylocarpon and Julbernardia globiflora are dominant species of the tree canopy with Pseudolachnostylis maprouneifolia abundant in the sub-canopy. No diagnostic grass species occur, however, the herbaceous vegetation is dominated by Andropogon gayanus, Digitaria milanjiana and Diheteropogon amplectens.

The study area incorporates a fine example of Miombo Woodland that has been protected from fire for at least eight years. The tall canopy reaches a height of 25-30 $\mathrm{m}$ and is composed of mostly Brachystegia spiciformis trees. Approximately $66 \%$ of the area is covered by the tree canopy. Many fire tender shrubs dominate the sub-canopy woody vegetation and obstruct the mean horizontal visibility to $27 \mathrm{~m}$ during the rainy season. The herbaceous vegetation is composed of many palatable grasses, yet there is minimal utilisation of this variation by game.

\subsection{Brachystegia spiciformis - Anthephora elongata High Closed Woodland vari- ation (burnt Miombo)}

This variation is described from nine relevés and is characterised by the presence of species group $\mathbf{J}$ (Table 1). Grasses are mostly unpalatable and are dominated by Tristachya superba, Microchloa kunthii and Zonotriche inamoena. Brachiaria grossa, Digitaria gayana and Eragrostis racemosa are diagnostic grasses, but because of their smaller size, are not conspicuous grass species. Afzelia quanzensis, Peltophorum africanum and Vitex madiensis are diagnostic woody species. Brachystegia spiciformis and Diplorhynchus condylocarpon are the dominant species of the tree canopy. The former requires some protection from fire to form a woodland canopy, while the latter is fire tolerant (Trapnell 1959; Lawton 1978).

This Miombo variation was exposed to hot fires prior to this study. Approximately $49 \%$ of the area is covered by the tree canopy. Sub-canopy woody plants are scarce and the mean horizontal visibility extends to $86 \mathrm{~m}$ during the hot dry season. The grass component is, however, well-developed and restricts the mean visibility during the rainy season to $44 \mathrm{~m}$. 
4. Euphorbia ingens - Enteropogon macrostachyus High Thicket Termitaria community

These termite mounds support a characteristic vegetation (Wild 1952) which have a distinct zonation that extends marginally into the surrounding woodland. Components of this vegetation are typical constituents of the deciduous Acacia-Colophospermum mopane Woodlands that occur at lower altitudes than the Miombo Woodlands. The similarity of the vegetation that occurs on the mounds to the low altitude woodlands could be because of differences in soil fertility, soil moisture conditions or reduced fire frequency and intensity when compared to Miombo Woodlands (Wild 1952).

This community is described from seven relevés and is characterised by the presence of species group M (Table 1). Diagnostic woody species are Balanites aegyptica, Boscia angustifolia and Maerua kirkii. Commiphora karibensis, Diospyros mespiliformis, Euphorbia ingens and Strychnos potatorum are conspicuous and dominant woody species. Capparis tomentosa and some Grewia species occur as sub-canopy woody plants that sometimes make the mounds almost impenetrable for large game. The grass layer is poorly developed and many of the termite mounds have an exposed soil surface. Enteropogon macrostachyus and Setaria homonyma are diagnostic grasses found on these mounds.

Numerous, large termite mounds are scattered throughout the study area, except in the wet dambo variation where the soils may be too wet for termites to establish themselves. The mounds occur at densities ranging from 1.6 to 4.6 mounds per ha, with a mean density of 2.6 mounds per hectare. These mounds provide palatable browse that is utilised heavily by greater kudu Tragelaphus strepsiceros, bushbuck Tragelaphus scriptus and common duiker Sylvicapra grimmia to such an extent that many distinct browse lines occur.
5. Albizia amara - Hylebates cordatus Tall Deciduous Thicket community

There is a wide diversity of plant species within this community. These are described from five relevés and represented by species group P (Table 1). Diagnostic woody species include Albizia amara, Canthium lactescens, Margaritaria discoidea and Rytigynia welwitschii. Further common woody species include Bridelia duvigneaudii, Canthium glaucum subsp. frangula, Dalbergia boehmii, Dioscorea dumetorum, Feretia aeruginescens, Landolphia parvifolia and Tricalysia ruandensis. Common forbs in this community include Begonia sutherlandii, Clerodendrum uncinatum, Craterostigma pumilum, Dorstenia cuspidatum, Ipomoea verbascoides, Plectranthus neochilus and Tragia benthonii. Hylebates cordatus is a diagnostic grass species.

This community has dense stands of woody vegetation with a closed tree canopy. The canopy reaches a height of approximately 15 $\mathrm{m}$. The thicket is composed of multiple layers of deciduous woody vegetation. The herbaceous vegetation mostly consists of forbs and only a few grasses are present. Fires are seldom able to penetrate this community. The community is sensitive to fire, and where fires do penetrate it, the canopy opens. Tall grasses dominate the vegetation in these open areas, which then readily support fires. The resulting vegetation then resembles the Chipya community as described by Lawton (1978). Chipya means fire in the Bemba language. Brachystegia spiciformis, which is typical of the Miombo Woodland, occurs at low densities in this fire-opened vegetation. Much of this community within the study area has not been influenced by fire. In its protected state, this community has a number of species in common with the vegetation of the termite mounds, presumably as a result of the lack of fire and the presence of the closed tree canopy. This community provides palatable browse and abundant cover that can support high bushbuck densities. 
- 1.1 Echinochloa colona - Leersia hexandra High Closed Grassland variation (Wet Dambo)

- 1.2 Panicum dregeanum - Acacia sieberiana Tall Closed Grassland variation (Dry Dambo)

\1.3 Echinochloa colona - Bauhinia thonningii Short Open Woodland variation (Raised Dambo)

口 2. Stereochlaena cameronii - Ziziphus abyssinica Tall Closed Woodland community (Munga)

- 3.1 Brachystegia spiciformis - Elionurus tripsacoides High Closed Woodland variation (Unburned Miombo)

$\Delta 3.2$ Brachystegia spiciformis - Anthephora elongata High Closed Woodland variation (Burnt Miombo)

$\times$ 4. Euphorbia ingens - Enteropogon macrostachyus High Thicket Termitaria community

+ 5. Albizia amara - Hylebates cordatus Tall Deciduous Thicket community

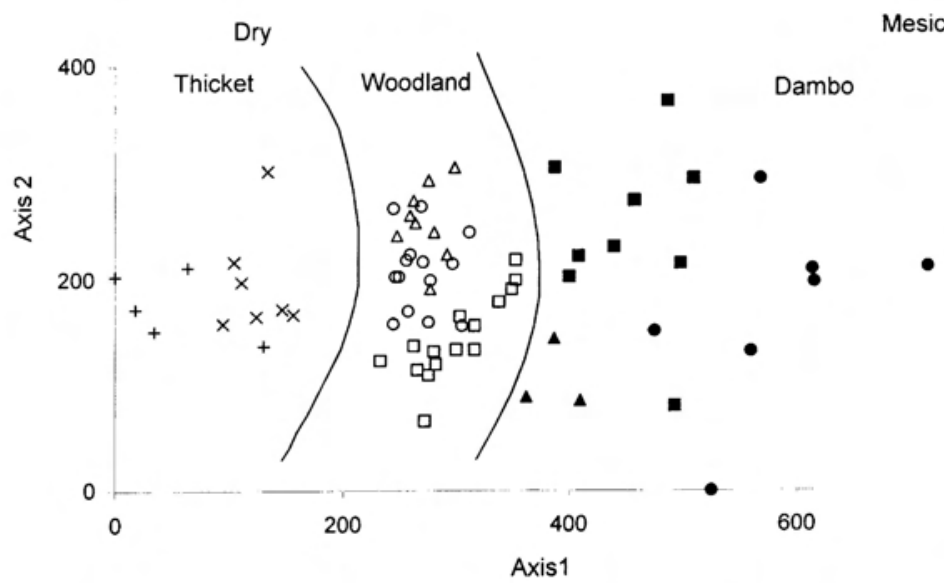

Fig. 4. Scatter diagram for the ordination of relevés representing the naturally occurring vegetation of Mtendere Game Ranch in the Chibombo District of the Central Province, Zambia.

\section{Ordination}

Figure 4 illustrates the distribution of all 69 relevés along the first and second axes of a DECORANA ordination. The vegetation types (Fanshawe 1971; White 1983) represented within the study area are clearly discernible. Axis 1 of the ordination represents an increasing soil moisture and a decreasing woody density gradient. This is clearly shown from left to right in Fig. 4. The influence of the availability of moisture, which has influenced the development of soils over long periods of time, is clear in the formation of $\mathrm{E}$ and $\mathrm{G}$ horizons and the presence of soft and hard plinthic B horizons. It is the combined effect of soils and moisture availability that determines the woody vegetation gradient. The discontinuity that is observed between the Deciduous Thicket and Miombo Woodland may be a sampling artefact. The fire-created Chipya Woodland is limited in size within the study area, and consequently it was not sampled adequately.

\section{Conclusions}

The vegetation in the study area is separated into three fire management units at the level of vegetation type, i.e. grassland (dambo), woodland and thicket. The dispersed nature of the termitaria makes it impossible to incorporate them into fire management units. The woodland communities show minimal separation from one another in the ordination (Fig. 4) and for practical purposes they can all be incorporated into a single management 
unit. The dambos exist as long narrow grasslands. Their adaptation to frequent and intense fires makes it imperative that they be separated from the woodlands as management units. The deciduous thickets support a great diversity of plant species that are worthy of conserving. This will require a different fire management policy directed specifically towards this community. Therefore the separation of the Deciduous Thickets from the woodlands as fire management units is advised.

\section{Acknowledgements}

We wish to express our sincere thanks to Prof. J. du P. Bothma for initiating this study and for his valuable criticism of the manuscipt. We are grateful to Mr and Mrs M. O'Donnell who provided accommodation on their game ranch and permitted us to undertake this work. We thank Mrs M. Deutschlander for assistance with the analysis of data. The assistance of Mr P. Phiri with the fieldwork is also greatly appreciated.

\section{References}

ACHARYA, U.R. \& N.S. BhASKARA RAO (eds.). 1981. Meteorology of Zambia. Part I. Lusaka: Government Printer.

ARNOLD, T.H. \& B.C. DE WFT (eds.). 1993. Plants of southern Africa. Memoirs of the Botanical Survey of South Africa no. 62.

AstLE, W.L, 1969. The vegetation and soils of Chishinga Ranch, Luapula Province, Zambia. Kirkia 7: 73-102.

BEHR, C.M. \& G.J. BREDHNKAMP. 1988. A phytosociological classification of the Witwatersrand National Botanical Garden. South African Journal of Botany 54: 525-533.

Bolnick, D. 1995. A guide to the common wildflowers of Zambia. Lusaka: Macmillan Publishers.

Chidmayo, E.N. 1987. Species structure in Zambian Miombo Woodland. Journal of Tropical Ecology 3:109-118.

EDWARDS, D 1972 Botanical survey and agriculture. Proceedings of the Grassland Society of southern Africa 7: 15-19.
EDWARDS, D. 1983. A broad-scale structural classification of vegetation for practical purposes. Bothalia 14: 705-712.

Fanshawe, D.B. 1971. The vegetation of Zambia. Lusaka: Government Printer.

HILL. M.O. 1979a. TWINSPAN - a fortran program for arranging multivariate data in an ordered two way table by classification of individuals and attributes, New York: Cornell University, Ithaca.

HILI, M.O. 1979b. DECORANA - a fortran program for detrended correspondence analysis and reciprocal averaging. New York: Cornell University, Thaca.

Hough, J. 1986. Management alternatives for increasing dry season base flow in the Miombo Woodlands of southern Africa. Ambio 15:341346.

Hutchinson, P. 1974, The climate of Zambia. Lusaka; Zambia Geographical Association (Occasional Study No. 7).

LAWTON, R.M. 1978. A study of the dynamic ecology of Zambian vegetation. Journal of Ecology 66: $175-198$.

Meul.Ler-Dombols. D. \& H. EllenberG. 1974. Aims and methods of vegetation ecology. New York: Wiley,

TrapNeL, C. G. 1959. Ecological results of woodland burning experiments in Northern Rhodesia. Journal of Ecology 47: 129-168.

Trapnele, C.G., M.T. Friend, G.T. Chamberlain \& H.F. BIRCH. 1976. The effects of fire and termites on a Zambian woodland soil. Journal of Ecology 64: 577-588.

WALTER, H. 1963. 1. Climatic diagrams as a means to comprehend the various climatic types for ecological and agricultural purposes. $\mathrm{Pp}, 3-9 . \mathrm{ln}$. RUTTER, A.J. \& F.H. WHITEHEAD (eds.). The water relations of plants. A symposium of the British Ecological Society. London 1961. London: Blackwell Scientific Publications.

WERGER, M.J.A. 1974. On concepts and techniques applied in the Zürich-Montpellier method of vegetation survey. Bothalia 11: 309-323.

WhITE, F. 1983. The vegetation of Africa. Paris Unesco.

WILD, H 1952, The vegetation of Southern Rhodesian termitaria. The Rhodesia Agricultural Journal 280-292.

Zambia Meteorological Department. 1997. Unpublished climate records for Kamaila weather station. Lusaka: Zambia Meteorological Department. 